MINERALOGIA, 44, No 3-4: 125-131 (2013)

DOI: 10.2478/mipo-2013-0009

www.Mineralogia.pl

MineRALOGICAL SOCIETY OF POLAND

POLSKIE TOWARZYSTWO MINERALOGICZNE

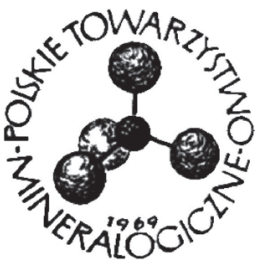

Original paper

\title{
Baddeleyite segregations in zircon of the Azov zirconium-rare-earth deposit (Ukrainian Shield)
}

\author{
Dmytro K. VOZNYAK ${ }^{1 *}$, Dariia S. CHERNYSH ${ }^{1}$, Volodymyr S. MELNIKOV ${ }^{1}$, \\ Stepanyda S. OSTAPENKO ${ }^{1}$ \\ ${ }^{I}$ M.P. Semenenko Institute of Geochemistry, Mineralogy and Ore Formation of National Academy of Sciences of \\ Ukraine, 34 Acad.Palladina prosp.,03680Kyiv,Ukraine; voznyak@igmof.gov.ua,chernysh@igmof.gov.ua \\ * Corresponding author
}

Received: December 27, 2010

Received in revised form: September 30, 2013

Accepted: March 15, 2014

Available online: July 28, 2014

Abstract. Baddeleyite as inclusions in zircon crystals is described for the first time from the ore zone of the Azov zirconium-rare-earth deposit in the Volodarsky (Pivdennokalchytsky) syenite Massif in the Ukrainian Shield. The main admixture in the zircon containing baddeleyite is hafnium $(0.68 \mathrm{wt} \%)$. The baddeleyite occurs in a substance that fills cracks and that probably corresponds to glass. The chemical compositions of four baddeleyite segregations, and of the hosting glass, are presented. The baddeleyite formed as a result of interaction between zircon and silicate melt with a low $\mathrm{SiO}_{2}$ content. The silicate melt formed under the influence of highthermobaric $\mathrm{CO}_{2}$-fluid flows on the rock.

Key-words: baddeleyite, zircon, high-thermobaric $\mathrm{CO}_{2}$-fluid flows, Azov zirconium-rare-earth deposit

\section{Introduction}

The Azov zirconium-rare-earth deposit (Ukrainian Shield; Fig. 1) is unique on account of its reserves, concentration of REE and the very simple mineral composition of the ore. The main ore minerals are zircon and britholite. Minor ore minerals are allanite and rareearth carbonates. 


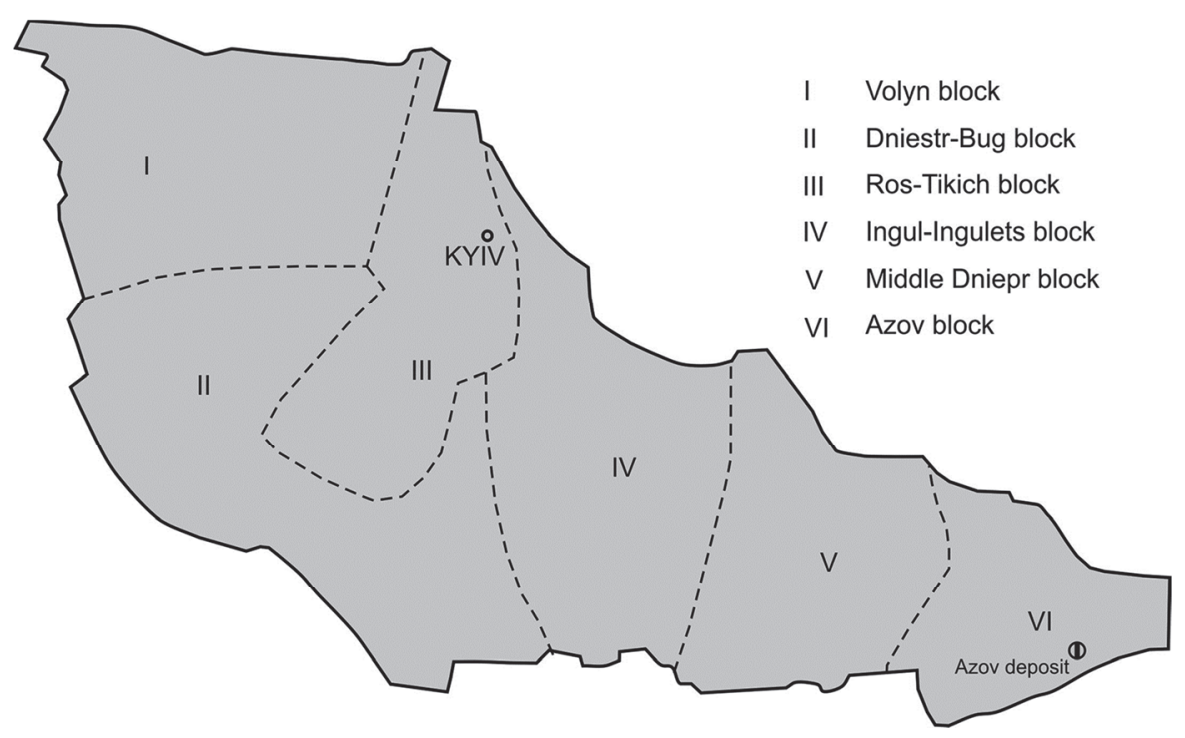

Fig. 1. Location of the Azov deposit within the Ukrainian Shield.

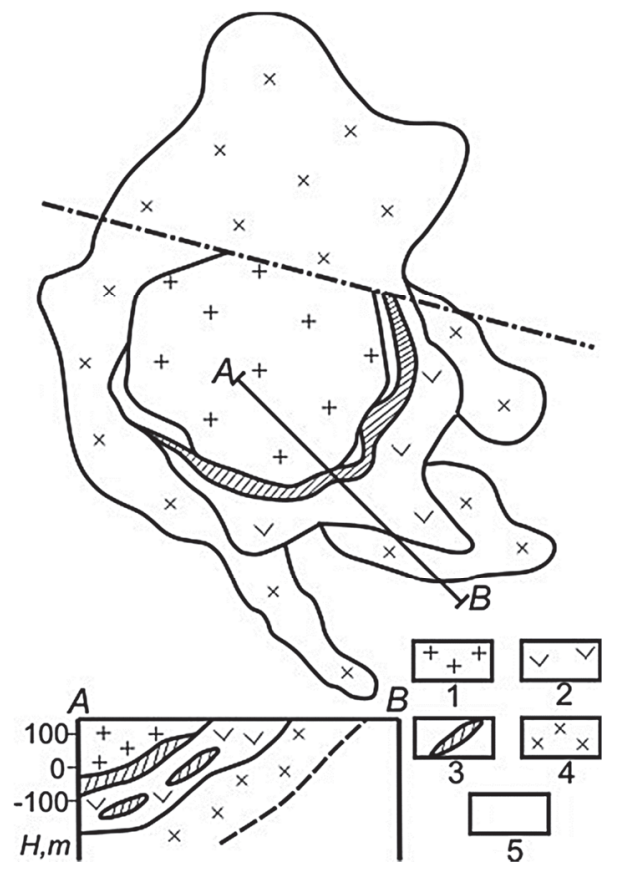

Fig. 2. The geological structure and section of the Azov deposit: 1 - biotite quartz syenite; 2 - taxitic syenite, differentiated, stratiform; 3 - ore horizons with zircon and rare earth minerals; 4 - "spotted" syenite, poorly differentiated; 5 - fayalite-hedenberhit syenites of Pivdennokalchytsky massif (Krivdik et al. 2000). 
The deposit is located within a syenite layered intrusion among rocks of the gabbrosyenite fomation of the Pivdennokalchytsky Complex (Fig. 2). The upper part of the intrusion consists of leucocratic biotite (lepidomelane) syenites. Melanocratic amphibole syenites containing alkali feldspar, ferrogastingsite, fayalite, hedenbergite are located below.

Zirconium in the Azov deposit was previously believed to have accumulated only in zircon (Melnikov et al. 2000; Melnikov 2005). For the first time in this deposit, we can reveal the presence of another zirconium mineral - baddeleyite - found included in a zircon crystal from the ore zone. This finding is important because it allows the genetic relationship between the dioxide (baddeleyite $-\mathrm{ZrO}_{2}$ ) and silicate (zircon $-\mathrm{Zr}\left[\mathrm{SiO}_{4}\right]$ ) of zirconium during the formation of the deposit to be evaluated. It is important to note that intergrowths of baddeleyite and zircon in igneous rocks are extremely rare (Bayanova 2006; Corfu et al. 2003).

Zircon occurs in variable amounts in all magmatic silicate rocks and baddeleyite is a typical accessory mineral of carbonatites (Baddeleyite 1965; Bayanova 2006). Baddeleyite is generally found in rocks of layered mafic intrusives, dolerite dikes, gabbro sills, anorthosites, kimberlites, alkaline syenites and in skarn ejecta from Vesuvius (Pascal et al. 2008). Rare occurrences of baddeleyite have also been reported from low-temperature rocks such as marine manganese nodules (Nayak et al. 2011). In exceptional cases, it may possibly result from the thermal decomposition of zircon $\left(>1676^{\circ} \mathrm{C}\right)$ in silica-rich melt. One such case recorded in Libyan-desert glass has been linked to shock compression (Godovikov 1975). However, the co-existence of baddeleyite and zircon in the rock does not indicate a genetic relationship between them; their formation may reflect an extended time interval and the independent development of each mineral under very different conditions.

\section{Samples}

Zircon crystals with an average size of $2-3 \mathrm{~mm}$ were investigated. About $10 \%$ of the crystals reached $10-15 \mathrm{~mm}$. The zircon is of pink color with a violet, rarely orange, tint. Colorless zircons are very rare. The crystals are characterized by both short- and long prismatic habits with a predominance of $\{110\}$ prisms. The prism $\{100\}$ is almost never seen. Crystal terminations are formed by the dipyramids $\{111\},\{331\}$ and $\{221\}$ though the last two, and $\{311\}$, are rare. Mostly transparent crystals with fluid inclusions were selected for study.

\section{Methods}

The phase transition temperatures of the content of $\mathrm{CO}_{2}$-solution inclusions were determined using a cryochamber (Voznyak 2007) in the range from +200 to $-196^{\circ} \mathrm{C}$ with an accuracy of $\pm 0.2^{\circ} \mathrm{C}$. Experimental quenching to glass was carried out using the heating device and a silit cylinder with an accuracy $\pm 20^{\circ} \mathrm{C}$ (Voznyak 2007).

A WD/ED combined microanalyzer JXA-8200 (JEOL, Japan) was used to provide the chemical composition of the zircons and their BSE images. 


\section{Results}

The main admixture in zircon containing baddeleyite is hafnium $-0.68 \mathrm{wt} \%$ (Table 1). The crystals contain small amounts of REE (sum of oxides -0.13 wt $\%$ ) and $\mathrm{Y}_{2} \mathrm{O}_{3}$ $(0.09 \mathrm{wt} \%)$. In other individual crystals $(\mathrm{n}=7), \mathrm{HfO}_{2}$ contents are slightly greater $(0.65$ $0.99 \mathrm{wt} \%)$ and amounts of REE oxides range from $0.13-0.58 \mathrm{wt} \%$ and $\mathrm{Y}_{2} \mathrm{O}_{3}$ from $0.00-$ $0.32 \mathrm{wt} \%$.
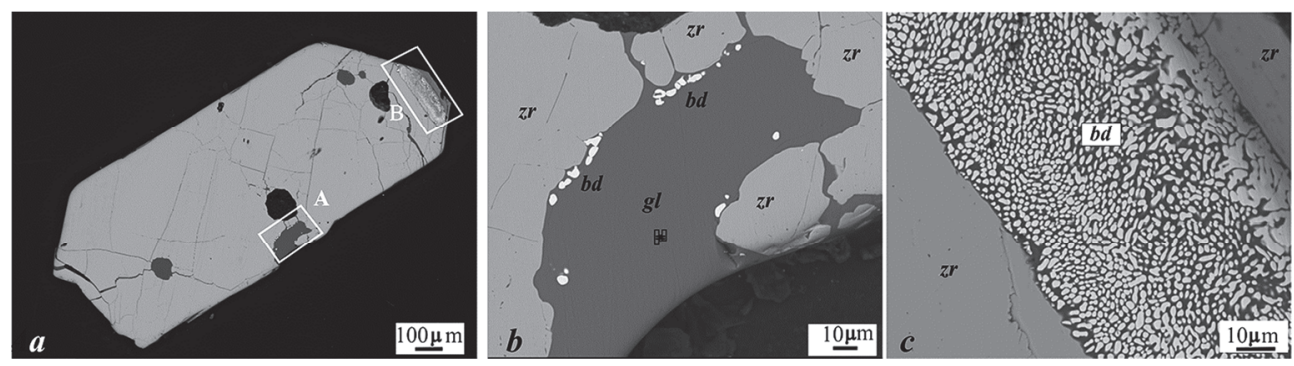

Fig. 3. BSE images of zircon crystal with numerous individual baddeleyite inclusions: a - general view of zircon with sites $\mathrm{A}$ and $\mathrm{B}$ indicated; $\mathrm{b}$ - detail at $\mathrm{A} ; \mathrm{c}$ - detail at $\mathrm{B}, z r$ - zircon; $g l$ - glass; $b d$ - baddeleyite.

TABLE 1

Chemical composition (wt $\%$ ) of zircon and baddeleyite, and of the substance hosting the baddeleyite

\begin{tabular}{lllllllll}
\hline Components & Zircon & \multicolumn{2}{l}{ Baddeleyite } & \multicolumn{7}{l}{ Glass } \\
\hline $\mathrm{SiO}_{2}$ & 32.91 & 2.74 & 0.73 & 9.21 & 11.42 & 46.03 & 43.24 & 44.27 \\
$\mathrm{ZrO}_{2}$ & 66.13 & 85.53 & 91.15 & 75.32 & 72.56 & 2.95 & 3.04 & 3.13 \\
$\mathrm{HfO}_{2}$ & 0.68 & 1.13 & 1.20 & 0.76 & 0.95 & 0.00 & 0.04 & 0.08 \\
$\mathrm{Al}_{2} \mathrm{O}_{3}$ & 0.00 & 2.82 & 0.50 & 6.54 & 7.10 & 24.78 & 27.00 & 26.47 \\
$\mathrm{FeO}$ & 0.01 & 0.65 & 0.44 & 1.20 & 1.40 & 4.23 & 4.02 & 4.73 \\
$\mathrm{MgO}$ & 0.02 & 0.07 & 0.04 & 0.15 & 0.19 & 0.48 & 0.53 & 0.52 \\
$\mathrm{CaO}$ & 0.03 & 1.99 & 2.30 & 3.12 & 3.44 & 9.16 & 11.11 & 9.85 \\
$\mathrm{Na} 2 \mathrm{O}$ & 0.00 & 0.12 & 0.02 & 0.39 & 0.53 & 1.72 & 1.51 & 1.71 \\
$\mathrm{Y}_{2} \mathrm{O}_{3}$ & 0.09 & 1.17 & 0.93 & 1.25 & 1.08 & 1.25 & 0.87 & 0.56 \\
$\sum \mathrm{REE}$ oxides & 0.13 & 1.27 & 1.45 & 2.04 & 1.85 & 3.39 & 1.74 & 1.54 \\
$\mathrm{Ta}_{2} \mathrm{O}_{5}$ & 0.13 & 0.09 & 0.02 & 0.00 & 0.03 & 0.00 & 0.00 & 0.26 \\
$\mathrm{P}_{2} \mathrm{O}_{5}$ & 0.00 & 0.00 & 0.00 & 0.00 & 0.01 & 0.36 & 1.37 & 1.70 \\
$\mathrm{Total}$ & 100.13 & 97.58 & 98.78 & 99.98 & 100.56 & 94.35 & 94.47 & 94.81 \\
\hline
\end{tabular}

WD/ED Combined microanalyzer JXA-8200, Technical Center of National Academy of Sciences of Ukraine; the analyst V.B. Sobolev

The baddeleyite occurs both as isolated individuals and dense aggregates (Fig. 3b, c) in the filling of cracks and funnels in a $1.5 \mathrm{~mm}$ long- and $0.6 \mathrm{~mm}$ wide zircon crystal (Fig. 3a). The baddeleyite aggregates (mainly 5-10 microns) are rounded- or elongated in shape, in some cases, irregular. They are located within the glass and are confined to the 
contact with the hosting zircon. As a result of dissolution, the mineral is rounded along the contact with glass (Fig. 3b). The chemical composition of four baddeleyite segregations indicates some chemical inhomogeneity in the grains (Table 1). The small grain size, and the influence of the composition of the matrix, may have led to some inconsistency in the analytical results.

The composition of the glass hosting the baddeleyite segregations is more or less constant (Table 1). The presence of unidentified volatile components in the glass, mainly $\mathrm{CO}_{2}$ and $\mathrm{H}_{2} \mathrm{O}$, might be the main cause of the analyses totalling about $95 \mathrm{wt} \%$.

\section{Discussion}

The origin of the baddeleyite in the Azov deposit is linked to the formation of the substance in which it occurs. There is no direct (X-ray) evidence that the hosting substance corresponds to glass (or partially crystalline glass). However, glass in the deposit occurs in primary fluid (in this text, the term "fluid" is used in its broadest sense, i.e. gas, liquid, melt). inclusions in zircon crystals, particularly where baddeleyite was found (Voznyak et al. 2000; Voznyak et al. 2010), and as secondary glass inclusions with a liquid $\mathrm{CO}_{2}$-fluid phase of both homogeneous- and heterogeneous capture (Kaluzhny 1982). In addition, the form of the segregations in the zircon crystal, and the more or less stable chemical composition, indicate that the substance containing the fine baddeleyite segregations corresponds to glass. The constant and elevated content of $\mathrm{ZrO}_{2}(2.95-3.13 \mathrm{wt} \%)$ in the glass and the constant lack (sum $\sim 5 \%$ ) of defined components is noteworthy. Clearly, the presence of glass in a crystalline medium-, coarse-grained igneous rock such as the Volodarsky syenite would indicate specific conditions for the formation of the glass. Because glass points to rapid cooling of a fluid substance, it is necessary to define the conditions that resulted in its appearance in this type of natural mineral.

As the primary inclusions in the zircon are always cracked (Fig. 4), and the secondary inclusions of glass are associated with a $\mathrm{CO}_{2}$-fluid phase, the cracking of the inclusions and the appearance of silicate melt are related, to the influence of high thermobaric $\mathrm{CO}_{2}$-fluid flows on the igneous (detail already given above) rock of the Azov deposit. Fluid flows of this type have been demonstrated in other parts of Ukrainian shield, e.g. during the formation of Mayske gold deposit, the lithium pegmatites of Kirovograd megablok and the Volyn chamber pegmatites (Voznyak et al. 2006).

Based on the results of cryometric analysis, the $\mathrm{CO}_{2}$ fluid of the secondary homogeneously-captured inclusions that are syngenetic to the glass inclusions in the zircon crystals of the Azov deposit, is characterized by a triple point temperature $\left(T_{\mathrm{tp}}\right)$ of $\mathrm{CO}_{2}=$ $-57.4--57.7 \pm 0.2^{\circ} \mathrm{C}$, a homogenization temperature $\left(T_{\mathrm{h}}\right)$ of $\mathrm{CO}_{2}$ (in liquid) $=17.5 ; 24.7-$ $27.0 \pm 0.2^{\circ} \mathrm{C}$ and a density $(\rho)=0.79 ; 0.67-0.70 \mathrm{~g} / \mathrm{cm}^{3}$ (Voznyak et al. 2010) which corresponds to the density of pure $\mathrm{CO}_{2}$ at $T_{\mathrm{h}} \mathrm{CO}_{2}$.

At these densities, pressures of 450-520 and 350-380 MPa correspond to temperatures of $1000-1200^{\circ} \mathrm{C}$ on the $\mathrm{CO}_{2}$ isochores.

The high-thermobaric $\mathrm{CO}_{2}$-fluid flows are not composed of pure $\mathrm{CO}_{2}$. The $T_{\mathrm{tp}}$ of the $\mathrm{CO}_{2}$ solution in the inclusions differs from the $T_{\mathrm{tp}}$ of pure $\mathrm{CO}_{2}\left(-56.6^{\circ} \mathrm{C}\right)$ in fluid inclusions probably because of the presence of admixtures of $\mathrm{CH}_{4}$ and/or $\mathrm{N}_{2}$. 

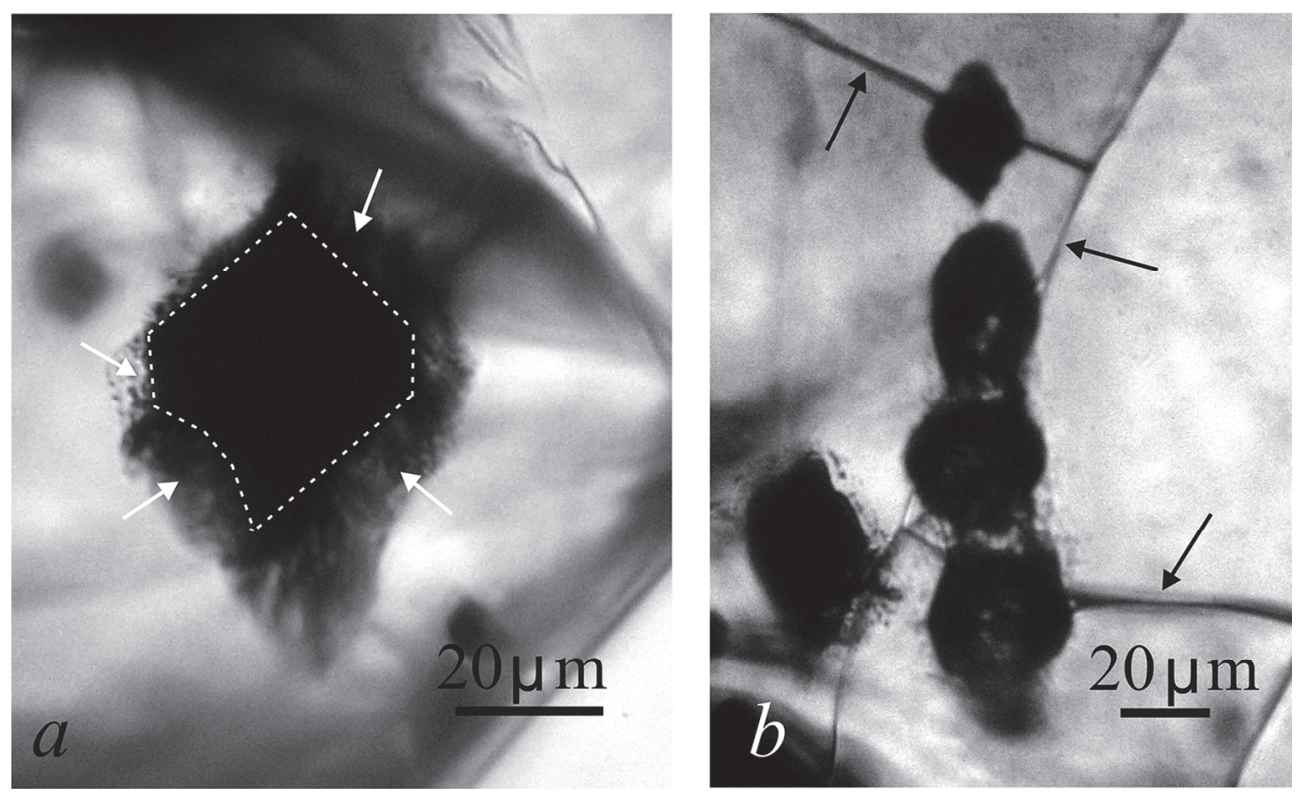

Fig. 4. Primary cracked fluid inclusions in zircon from the Azov deposit: $a$ - aureole of cracking (indicated by arrows) of submicroscopic inclusions (highlighted by dotted line); $b$ - chain of slightly cracked inclusions, elongated along the crystal lengthening of the zircon crystal. All inclusions are damaged by unhealed dry cracks (shown by arrows).

The baddeleyite was formed as a result of interaction between zircon and silicate melt with a low $\mathrm{SiO}_{2}$ content (43-46 wt\%; Table 1). The elevated content of $\mathrm{ZrO}_{2}$ (2.95$3.13 \mathrm{wt} \%)$ in glass is noteworthy. The melt that participated in the growth of the baddeleyite had at least the same content of zirconium. The zirconium for baddeleyite growth derived from zircon.

It is known that in silica-undersaturated basic rocks and carbonatites, baddeleyite can both predate and postdate zircon; baddeleyite grains are found within zircon crystals (Voznyak et al. 2000; Melnikov et al. 2000; Corfu et al. 2003) and on their surfaces (Corfu et al. 2003). In its form, occurrence and mode of formation, baddeleyite from kimberlitic zircon (Corfu et al. 2003) is similar to that identified in the Azov deposit. In our view, faced forms of baddeleyite individuals in kimberlitic zircon indicate crystallization at much slower cooling compared to baddeleyite from the Azov deposit that is characterized by fine rounded drop-like grains. This reflects the fact that kimberlite is heated to higher temperatures during the formation of baddeleyite compared to those attained in the Azov deposit due to the flow of high-temperature $\mathrm{CO}_{2}$-fluid.

\section{Conclusions}

Baddeleyite in the Azov deposit is younger than zircon. It was formed due to interaction between zircon and silicate melt with a low $\mathrm{SiO}_{2}$ content (43.24 - $46.03 \mathrm{wt} \%$ ). Silicate melt appeared under the influence of high-thermobaric $\mathrm{CO}_{2}$-fluid flows in the rock. The cracks 
holding the generated melt in the zircons are small. When the heated rock around the cracks stopped receiving $\mathrm{CO}_{2}$ fluids, its heated mass would have rapidly cooled to the temperature of enclosing rocks. The heated rock immediately surrounding the zircon crystal would have rapidly cooled to the temperature of the enclosing rocks after stopping of the fluid coming. With this rapid decrease in temperature, the silicate melt solidified as a glass with the formation of fine baddeleyite segregations in zircon crystals.

Acknowledgements. Thanks are due to V.B. Sobolev (Technical Center of National Academy of Sciences of Ukraine) and to an anonymous reviewers for their constructive comments of this manuscript and corrections in English text.

\section{References}

Baddeleit (1965). In Ph. C. Chukhrov (Ed.), Mineraly, Spravochnik, (V. 2, Issue. 2, pp. 130-136). Moskva: Nauka (in Russian).

Bayanova, T.B. (2006). Baddeleit: perspektivnyj geochronometr shchelochnogo i bazitovogo magmatizma. Petrologija, 14(2), 203-216 (in Russian).

Corfu, F., Hanchar, J.M., Hoskin, P.W.O., \& Kinny, P. (2003). Atlas of Zircon Textures. Reviews in Mineralogy and Geochemistry, 53(1), 469-500.

Godovikov, A.A. (1975). Mineralogija. Moskva: Nedra (in Russian).

Kaluzhny, V.A. (1982). Osnovy uchenija o mineraloobrazujushhih fljuidah. Kiev: Naukova Dumka (in Russian).

Krivdik, S.H., Zahnitko, V.M., Strekozov, S.M., Hurskyj, D.S., Vasylchenko, V.V., \& Matvijchuk, M.V. (2000). Ridkisnometalevi siyenity Ukrayins'koho shhyta: perspektyvy poshukiv bahatyx rud cyrkoniyu ta lantanoyidiv. Myneralohycheskyj zhurnal. 22(1), 62-72 (in Ukrainian).

Melnikov, V.S., Voznyak, D.K., Grechanovskaya, E.E., Hurskyj, D.S., Kulchitskaya, A.A., \& Strekozov, S.N. (2000). Azovskoe cirkonij-redkozemel'noe mestorozhdenie: mineralogicheskie i geneticheskie osobennosti. Myneralohycheskyj zhurnal, 22(1), 42-61 (in Russian).

Melnikov, V.S. (2005). Geneticheskaja model' Azovskogo mestorozhdenija. Zbirnyk naukovyx prac' Ukrayins'koho derzhavnoho heolohorozviduval'noho instytutu, (1), $92-99$ (in Russian)

Nayak, B., Das, S.K., \& Bhattacharyya, K.K. (2011). Detrital and authigenic(?) baddeleyite $\left(\mathrm{ZrO}_{2}\right)$ in ferromanganese nodules of Central Indian Ocean Basin. Geoscience Frontiers (Elsevier), 2(4), 571-576.

Pascal, M.-L., Di Muro, A., Boudouma, O., Fonteilles, M., \& Principe, C. (2008). Zirconlite, calzirtite, baddeleyite, betafite, geikielite and qandilite in skarn ejecta from Vesuvius - inferences for the magmawallrock interactions. EGU General Assembly. Geophysical Research Abstract, 10, EGU2008-A-06674, 2008.

Voznyak, D.K. (2007). Mikrovklyuchennya ta rekonstrukciya umov endohennoho mineraloutvorennya. Kyyiv: Naukova Dumka (in Ukrainian).

Voznyak, D.K., Kulchitskaya, A.A., Melnikov, V.S., Pavlishin, V.I., \& Strekozov, S.N. (2000). K uslovijam obrazovanija Azovskogo cirkonij-redkozemel'nogo mestorozhdenija (po fljuidnym vkljuchenijam v cirkone rudnoj zony). Heolohiya i mahmatyzm dokembriyu Ukrayins'koho shhyta. Kyyiv. (ss. 140-142) (in Russian).

Voznyak, D.K., Melnikov, V.S., Chernysh, D.S., \& Ostapenko, S.S. (2010). Influence of $\mathrm{CO}_{2}$-fluid flows on forming of Azov Zr-REE deposit (Ukrainian Shield). Abstracts $-3^{\text {rd }}$ Biennial Conference of Asian Current Research of Fluid inclusions (ACROFI III) and $14^{\text {th }}$ International Conference on Thermobarogeochemistry (TBG XIV), 15-20 September 2010 (ss. 260-261). Novosibisrsk, Russia. V.S. Sobolev Institute of Geology and Mineralogy, Russian Academy of Sciences, Siberian Branch.

Voznyak, D.K., \& Pavlishin, V.I. (2006). Vysokotermobaricheskie potoki $\mathrm{SO}_{2}$-fljuida i mineraloobrazovanie (na primere Ukrainskogo shhita). Materialy mezhdunarodnogo simpoziuma - Sovremennye metody issledovanij i perspektiva ispol'zovanija vkljuchenij mineraloobrazujushhih sred v nauke i praktike «APIFIS-III». Uzbekistan, Tashkent, 1-4 nojabrja (ss. 101-106). Tashkent, Uzbekistan. Tashkentskij Gosudarstvennyj Tehnicheskij Universitet (in Russian). 